ISSN 1997-5902

\title{
Determination of grasscutter age (Thryonomys swinderianus Temminck, 1827) from anogenital distance
}

\author{
SACRAMENTO1 ${ }^{1}$ Tèniola Isabelle, SINABARAGUI2 Olivier Sourokou, AIZOUN² Frédéric, FAROUGOU2 \\ Souaïbou, MENSAH ${ }^{3}$ Guy Apollinaire, ATEGBO1*Jean-Marc \\ ${ }^{1}$ Department of Animal Physiology, Faculty of Science and Technology, University of Abomey-Calavi BP 526 \\ Cotonou, Benin. \\ ${ }^{2}$ Department of Animal Production and health, Biotechnology Research Unit of Production and Animal Health, \\ Polytechnic School of Abomey-Calavi, 01 BP 2009 Cotonou, Benin. \\ ${ }^{3}$ National Institute of Scientific Research, Research Center of Agonkanmey (CRA/INRAB), Abomey-Calavi. \\ Corresponding author \\ *Professor ATEGBO Jean-Marc, Department of Animal Physiology, Faculty of Science and Technology, University \\ of Abomey-Calavi, 06 BP 2584 Cotonou, Benin. Phone: (229)95877883/66648655/93989313/98111519 E-mail: \\ jmarcategbo@yahoo.fr/marc.ategbo@fast.uac.bj \\ Original submitted in on 20th November 2012. Published online at www.m.elewa.org on $27^{\text {th }}$ February 2013.
}

\begin{abstract}
Objectives: The global objective of the survey was to determine the grasscutter age from the anogenital distance.

Methodology and results: Some linear (anogenital distance) and weight measurements were taken on 390 anesthetized grasscutters (202 males and 188 females) aged from two weeks to 12 months. The results led to eight linear prediction equation models of grasscutter age from anogenital distance and body weight. The best determined grasscutter age with an elevated coefficient value was: Age $=-5.50+0.37 \times$ DAG + $0.01 \times$ WT with $R^{2}=0.98$. The Equation determining grasscutter age with a weak determination coefficients value was: Age $=-18.22+1.26 \times$ DAG with $R^{2}=0.88$. These models of equations can be used by literate breeders or researchers and in semi-intensive and intensive raisings.

Conclusions and application of findings: These results are useful to predict not recorded age of raised grasscutter, estimate game grasscutter age, make better management of reproduction and a good sanitary follow-up, and improvement of farming conditions, compare wild and raised grasscutter meat since meat organoleptic quality generally varies according to age.
\end{abstract}

Key words: Benin, vulva, testes, brown coloration, age, model.

\section{INTRODUCTION}

Grasscutter (Thryonomys swinderianus Temminck, 1827 ) is a rodent whose closed captive breeding has grown more and more in West and Center Africa for reasons of both food and wildlife management (Alogninouwa et al. 1993; Jori et al.1995; Edderai et al.2001). In eight years, the number of grasscutter farmers has increased tenfold, from 300 in 1996 to 3.000 in 2004.
Similarly, the herd has exploded and between 2002 and 2004 their number doubled. This success is the result of years of research and extension on breeding methods, not only in Benin but also in Ivory Coast and sixteen other countries in West and Central Africa Azéhoun-Pazou et al. 2004a; Azéhoun-Pazou et al. 2004b). In Benin, Grasscutter meat production as livestock reduces 
the hunting of this species and deforestation due to bush fires caused by hunters Alogninouwa et al. (1993). In 1996, almost all of the 200.000 grasscutters consumed in South Benin came from hunting, endangering the survival of the species. Today, 72.000 of these animals are bred in captivity. Although many scientific studies have been devoted to grasscutter in recent decades, determining glasscutters' age is still a problem. Birth registration and use of dental formula are the most used parameters for locating age in modern breeding (Adjanohoun, 1988). Weighing of dry crystalline, a method of age determination can also determine age of some rodents (Martinet, 1966; Le Louarn, 1971; Abdelmalek-Mounir, 1989; Quéré, 1989) regardless of grasscutter. This study has provided growth curves of crystalline weight according to age, with age on a logarithmic scale. The reference curves were constructed by fitting a logarithmic function to the observed values. The weight is a function of age, the curves have been translated by straight lines $Y=X+b \log _{10}$ where $Y$ is the average weight of crystalline $\mathrm{mg} X$ and the corresponding age in months (30 days). Age of game and unregistered farming grasscutter remains unknown. Aware that meat quality varies with age, age determination of game grasscutter in order to compare sensory, microbiological and technological quality of its meat to that of reared grasscutter is essential. While Baku et al. (2003) argue that preponderance of glycolytic fibers in the muscles of grasscutter thigh, fineness of the collagen and presence of intramuscular adipose tissue are features that help to explain the excellent organoleptic quality of meat; they do not

\section{MATERIALS AND METHODS}

Study environment and animal management: Data from this study were collected in the department of Plateau, in the Commune of Adja-Ouèrè located in the borough of Tatonoukon, southeast of Benin. The grasscutter 3000 in number are raised above ground. Individual boxes of $2 \mathrm{~m}$ square and $0.5 \mathrm{~m}$ high, constructed entirely of solid materials were stacked on three levels along the walls and the center of buildings. The enclosures contained compartments separated by a bulkhead on the width of the enclosure. The address the quality of breeding grasscutter meat based on age.

According to Mensah et al. (2007), grasscutter anogenital distance is $8.0 \pm 3.9 \mathrm{~mm}$ for a male embryo and $3.5 \pm 2.0 \mathrm{~mm}$ for a female embryo, $38.0 \pm 7.2 \mathrm{~mm}$ for an adult male and $12.2 \pm 0.2$ $\mathrm{mm}$ for an adult female. At birth, it is $0.8 \mathrm{~cm}$ for males and $0.4 \mathrm{~cm}$ for females. At 4 months old, male's anogenital distance is $2.8 \mathrm{~cm}$ against 0.8 $\mathrm{cm}$ in females. Heymans (1996) noted that the development of male genital organ reached anogenital distance which increases from $1 \mathrm{~cm}$ to $\pm 4 \mathrm{~cm}$ on adult. Therefore, the anogenital distance varies depending on grasscutter age and sex. To our knowledge, on the evaluation of anogenital distance, no publication is dedicated, to age determination from anogenital distance. This study aims to answer, in part, to this concern by the measurement of the anogenital distance. This work will not only easily evaluate the grasscutter age for a comparative study between game and breeding grasscutter, but use much more not registered grasscutter in farms for breeding.

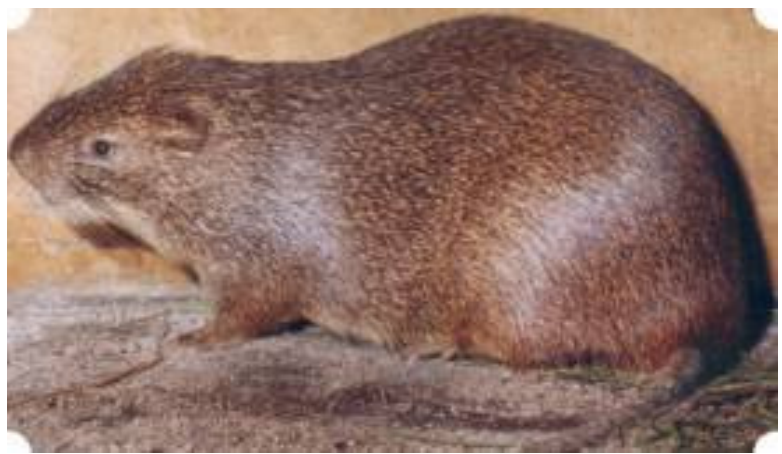

Figure 1: Grasscutter (Thryonomys swinderianus Temminck, 1827)

compartments communicated through openings of 20 inches square or diameter for passage of animals from one compartment to another. A side opening was fitted on each enclosure with a screen door. The feed was varied and in line with that consumed in nature. The diet consisted mainly of:

- $\quad$ Fodder: Pennisetum purpureum, Panicum maximum, Saccharum spp, Andropogon gayanus, Leucaena leucocephala. The grasses were cut into 
pieces before serving. They were freshly distributed in the racks;

- $\quad$ Sugar cane, kitchen scraps and by-products of agro-industrial and feed supplementing that diet. This feed was manufactured on site with the following ingredients: corn, cassava chips, salt, oyster shell powder, and Leucaena leucocephala powder (Table 1).

Table 1: Composition of the dietary supplement

\begin{tabular}{l|c|c}
\multicolumn{1}{c|}{ Food ingredients } & Food quantity (g) & Percentage (\%) \\
\hline Grain corn/cassava chips & 8.514 & 81.7 \\
Corn bran & 1 & 9.6 \\
Leucaena leucocephala Powder & 100 & 1.0 \\
Oyster Shell Powder & 500 & 4.8 \\
Salt & 300 & 2.9 \\
Total & 10.414 & 100.0 \\
\hline
\end{tabular}

Feed was distributed in the troughs of cement. Every morning at 8 o'clock and each evening at 18 o'clock, animals were fed on fodder and food supplement was served at noon. Water was given ad libitum in cement troughs. Health monitoring of animals was about disease prevention and health medical prophylaxis. Diseases of grasscutters were treated in this breeding center using medicinal plants and sometimes veterinary products. Deworming was done internally with papaya seeds and leaves of Moringa oleifera.

Animals: sample of 390 grasscutters including 202 males and 188 females was used in this study. They ranged in age from 2 weeks to 12 months (Table 2). They are watered and fed ad libitum with a foragebased diet and dietary supplement.

Table 2: Distribution of animal material by age

\begin{tabular}{cccc}
\hline Ages (months) & \multicolumn{3}{c}{ Number of grasscutters } \\
\cline { 2 - 4 } & Males & Females & Total \\
\hline $1 / 2$ & 15 & 14 & 29 \\
1 & 16 & 15 & 31 \\
2 & 18 & 12 & 30 \\
3 & 17 & 16 & 33 \\
4 & 15 & 12 & 27 \\
5 & 20 & 12 & 32 \\
6 & 17 & 11 & 28 \\
7 & 13 & 17 & 30 \\
8 & 17 & 16 & 33 \\
9 & 14 & 13 & 27 \\
10 & 11 & 17 & 28 \\
11 & 14 & 18 & 32 \\
12 & 15 & 15 & 30 \\
Total & 202 & 188 & 390 \\
\hline
\end{tabular}

Other Material

Restraint Equipment: The restraint equipment that was used in this study was as follows:

- Jute bags in which animals were put before the weigh-ins;

- $\quad$ Mesh crates in which animals were put before anesthesia.

Anesthetic equipment

- $\quad 2 \mathrm{ml}$ syringes and disposable needles;
- Two anesthetics: xylazine hydrochloride (ROMPUNND) and ketamine hydrochloride (IMALGENEND). They were used in equal volume in the syringe at a dose of $0.1 \mathrm{ml} / \mathrm{kg}$ body weight.

\section{Measuring equipment}

- $\quad$ an ordinary load cell capacity of $10 \mathrm{~kg}(50 \mathrm{~g}$ scale) for measurement of body weight; a caliper precision $1 / 1000 \mathrm{~mm}$ and a tape measure for linear measurements and body cane rats; 
- $\quad$ sheets for recording measured data.

Manual restraint of grasscutter: Before any measurement, the animals were manually restrained. This manual restraint has been shown by Mensah \& Ekué, (2003) and Mensah et al., (2007):

- $\quad$ seize the animal almost at the base of the tail;

- $\quad$ raise its hindquarters so that only the front legs are resting on the floor of the block

- $\quad$ Then, slowly, carefully lift it completely from the ground making sure it does not turn on itself, because in this case the tail may dislocate and break.

Once the animal content, it was introduced into the burlap bag and hung on the spring scale to gain weight.

Measurement of anogenital distance: The measurement of anogenital distance involved all grasscutters of all ages and sexes. For the success of this operation, three persons were used. In addition, disinfection of the caliper should be careful done to avoid transmission of diseases from one animal to another. The measurement was made from smaller to larger. Operations, which were repeated three times, took place as follows:

- $\quad$ contention grasscutter supine;

- $\quad$ installation of the caliper between the upper end of the anus and the lower end of the vulva;

- $\quad$ Paired reading distance for accuracy.

The measurements of a rodent's anogenital distance, applied to grasscutters, were performed following the method inspired by Rosevear (1969) and used by Sicard et al. (1995). To perform these measurements, the grasscutter was lying on its back and its head facing the left side. This allowed easy access to measurements on the same side and at different ages as follows: 2 weeks, 4 weeks, 8 weeks, 12 weeks, 16 weeks, 20 weeks, 24 weeks, 28 weeks, 32 weeks, 36 weeks, 40 weeks, 44 weeks and 48 weeks at a frequency of once a week. 5 to $10 \mathrm{~min}$ after anesthesia, grasscutters were removed from the cage and installed for linear measurements and body weight.

Method of anesthesia of the grasscutter: Once the weighing was completed, the grasscutter was taken out of the bag and then introduced into the restraining cage where it was anesthetized. Using $2 \mathrm{ml}$ short syringes,

\section{RESULTS}

Simple Linear Model: Equations for age estimation based on anogenital distance and coefficient of small diameter and single-use needles, a mixture of equal volumes of xylazine hydrochloride (Rompun $2 \%$ ND) and ketamine hydrochloride (Imalgene 1000 ND) was used in the same syringe at a dose of $0.1 \mathrm{ml} / \mathrm{kg}$ body weight. This method for anesthetizing grasscutter was indicated by Adjanohoun (1986) and Farougou (1992) because the two products used separately are poorly tolerated by this rodent (Adjanohoun, 1988). On the basis of animal body weight, the dose injected in each animal was calculated. This mixture injected intramuscularly (IM) at the base of the tail, yielded a good sedation with excellent muscle relaxation at low doses. Anesthesia was effective after 5 to 10 minutes and the grasscutter slept for 30 to 60 minutes before its effect wore off. This time was sufficient to take all linear measurements on the animal. All measurements were taken early morning before feeding to avoid skewing the data and frequency of once a week. Pregnant females were excluded from the study.

Statistical analyses: The collected data were entered, coded and recorded using the Excel 2007 before being processed. Descriptive statistics were performed. The pairwise comparisons of means were performed using Student's test. The relationship between ages and various body measurements and weight were determined by calculating the correlation matrix between variables. This correlation provided guidance on the simultaneous evolution of the variables taken in pairs. The coefficients of determination $\left(R^{2}\right)$ for the MLS and the Akaike Information Criterion (AIC) for the MLG were used to identify the best equation models. For establishing prediction equations, it was the simple linear model (SLM) and the generalized linear model (GLM) that were used. In general, a predictive model is any equation that can be put in the form of: $y=a x+b$, with $y$ the dependent variable, $b$ the value of $y$ when $x=$ 0 ; a change of $y$ for any change in a unit of $x$, and $x$ is the independent variable. Once developed, these models were used from independent samples. For data processing we used the software R 2.10.0 with lots of packages (MASS, FactoMineR,).

determination $\mathrm{R}^{2}(\%)$ in male and female were indicated in Table 3. 
Table 3: Simple Linear Model for grasscutter age estimation from anogenital distance and body weight.

\begin{tabular}{lccc}
\hline Male & \multicolumn{2}{c}{ Female } \\
\hline Equations & $\mathrm{R}^{2}(\%)$ & Equations & $\mathrm{R}^{2}(\%)$ \\
Age $=-18.22+1.26 . \mathrm{DAG}$ & 88 & $\mathrm{Age}=-8.50+2.76 . \mathrm{DAG}$ & 95 \\
Age $=-5.50+0.37 . \mathrm{DAG}+$ 0.01.PV & 98 & Age $=-7.42+2.13 . \mathrm{DAG}+4.8 .10^{-3} . \mathrm{PV}$ & $\mathbf{9 6}$ \\
\hline
\end{tabular}

DAG: anogenital distance, PV: Live body weight

Generalized Linear Model: Equations for age estimation based on anogenital distance and Akaike
Information Criterion (AIC) in male and female were indicated in Table 4.

Table 4: Generalized Linear Model for grasscutter age estimation from anogenital distance and body weight.

\begin{tabular}{lccc}
\hline Male & \multicolumn{3}{c}{ Female } \\
\hline Equations & AIC & Equations & AIC \\
Age $=\exp (0.38+0.08 . \mathrm{DAG})$ & 1051 & Age $=\exp (1.56+0.12 . \mathrm{DAG})$ & 1174.5 \\
Age $=\exp \left(5.42 .10^{-1}+6.78 .10^{-2} \cdot \mathrm{DAG}+\right.$ & 1048,7 & Age $=\exp \left(1.60+1.09 .10^{-1} . \mathrm{DAG}+\right.$ & 1175.8 \\
$7.12 .10-5 . \mathrm{PV})$ & & $\left.8.22 .10^{-5} . \mathrm{PV}\right)$ & \\
\hline
\end{tabular}

DAG: anogenital distance, PV: Live weight body

Age Prediction was established on two models types: the simple linear model (SLM) is writing in the form: $a_{1}$ (sex) $+a_{2}(D A G)+a_{3}(w)+b$ and the generalized linear model (GLM) which is of the form: $\exp \left(a_{1}\right.$ (sex) $+a_{2}$ $\left.(D A G)+a_{3}(w)+b\right)$. The resulting models with anogenital distance only had a determination coefficient $\left(R^{2}\right)$ and an AIC less significant than $R^{2}$ and AIC models from the combination of body weight and anogenital distance. Therefore, $\mathrm{R}^{2}$ and AIC have led to choose the best models for age predicting of the

\section{DISCUSSION}

Age determination from anogenital distance: Work on the measurement of anogenital distance has yielded results which prove that anogenital distance as well as weight in grasscutter evolves with age. Similarly, measurements of anogenital distance recorded are consistent with those of Mensah et al. (2007) who find a value of $8.0 \pm 3.9 \mathrm{~mm}$ for male embryo, $3.5 \pm 2.0 \mathrm{~mm}$ for female embryo, $38.0 \pm 7.2 \mathrm{~mm}$ for an adult male and $12.2 \pm 0.2 \mathrm{~mm}$ for an adult female. At birth, it is about $0.8 \mathrm{~cm}$ in males and $0.4 \mathrm{~cm}$ in females. At the age of 4 months, anogenital distance of males becomes $2.8 \mathrm{~cm}$ against $0.8 \mathrm{~cm}$ in females. Yewadan \& Schrage (1995) also shows that anogenital distance at birth is $0.8 \mathrm{~cm}$ for males and $0.4 \mathrm{~cm}$ for females. At the age of 4 months, that of males becomes $2.8 \mathrm{~cm}$ against $0.8 \mathrm{~cm}$ in females. On the other hand, Heymans (1996) noted that the development of penis i.e. the development of male genital organ increased grasscutter. To identify the type of model (GLM or MLS) that suited this work, the bias that is the difference between actual age and estimated age was evaluated. This assessment identified the best models Age $=-5.50$ $+0.37 \mathrm{DAG}+0.01 \mathrm{PV}$ with $\mathrm{R}^{2}=0.98$ for males and $7.42+2.13 \mathrm{DAG}+4.8 .10^{-3} \mathrm{PV}$ with $\mathrm{R}^{2}=0.96$ for females. The AIC was used for the GLM and $R^{2}$ for MLS in order to choose the best model in each case. More AIC is little, better is the model.

anogenital distance passing of $\pm 1 \mathrm{~cm}$ at birth to $\pm 4 \mathrm{~cm}$ in adults. These results are slightly higher than those obtained by Asibey (1974) which indicates that at birth, anogenital distance is $10 \mathrm{~mm}$ in males and less than 5 $\mathrm{mm}$ in females. In adults, the measure is an average of $38 \mathrm{~mm}$ from the study of newborns and $12 \mathrm{~mm}$ in 67 females studied. The best equations, Age $=-5.50+$ 0.37.DAG + 0.01.PV with $\mathrm{R}^{2}=0.98$ for males and -7.42 $+2.13 . D A G+4.8 \cdot 10^{-3}$. $P V$ with $R^{2}=0.96$ for females are finally selected for age estimation. The body weight significantly improved coefficients of determination for equation models drawn strictly from anogenital distance. Similar works on age determination from body characters that evolve according to age were conducted on some rodents Hounzangbe-adote et al. (2004). The reference method, the lens weighing, is generally too restrictive and the result can be obtained after several weeks. This is the case revealed by Quéré 
et al. (1989) on the gray field mouse (Apodemus sylvaticus L. 1798), Martinet (1996) on the meadow vole and Barker et al. (2003) on Tamias amoroenus from the Rocky Mountains of Alberta. The experience helped them, from the mass of the lens, to distinguish juveniles from adults, but not adults of different ages. Poulet (1980) determined the age by weighing the crystals in five species of rodents (Muridae and

\section{CONCLUSION}

Measurements of anogenital distance and body weight has shown that the growth of anogenital distance in males is stabilized between the $11^{\text {th }}$ and $12^{\text {th }}$ months of age with a mean of $47.2 \pm 1.5$ months while it continues in females. Best linear regression equations

\section{REFERENCES}

Abdelmalek-Mounir, Mise au point de la méthode de détermination des âges à partir des poids secs de cristallin, de variables craniométriques et morphologiques chez Meriones shawi (Duvernoy, 1842) Rodentia-Gerbillidae de la région Guelmin. Mém. 2è cycle Institut Agronomique et Vétérinaire Hassan 2 Rabat, 1989, $90 \mathrm{p}$.

Adjanohoun E, Comportement, Stress, Contention et Anesthésie de l'aulacode en captivité étroite, PBAA/DEP/MDRAC, 1986 (Inédit).

Adjanohoun $E$, Contribution au développement de l'élevage de l'aulacode (Thryonomys swinderianus, TEMMINCK, 1827) et à l'étude de sa reproduction, thèse de Doctorat d'Etat ENV d'Alfort, 1988, 198p.

Alogninouwa Th, Yewadan LT, Schrage R, Biologie de l'aulacode (Thryonomys swinderianus) en Afrique Tropicale. Bull. Mens. Office National de la Chasse, 1993, 81-84.

Asibey EOA, The grass cutter (Thryonomys swinderianus Temminck) in Ghana, Symp. Zool. Soc. London, 34, 1974, 161-170.

Azéhoun-Pazou J, Adégbidi A, Biaou F, Mensah GA, Circuits et acteurs de commercialisation de l'aulacode d'élevage dans les départements du Mono et du Couffo au sud-ouest du Bénin, Bul. REc. Agr. Bénin, N46, 2004a, 42-48.

Azéhoun-Pazou J, Adégbidi A, Biaou F, Mensah GA, Caractérisation du marché d'aulacode d'élevage dans le sud-ouest du Bénin, Bul. REc. Agr. Bénin, $N^{\circ} 45,2004 b, 9-16$.

Bakou S, Aoossi S, Kane Y, Cherel Y, Wyers M, Etude histomorphométrique des muscles de la
Gerbillidés) from western Africa. This study provided growth curves of crystalline weight for different ages (with age in logarithmic scale). Marchandeau et al. (1995) also determined age of young rabbits, Oryctolagus cuniculus, according to their weight. Unlike this work, this study estimates the age of live animals, with an easy technique, reliable and inexpensive. It also helps to preserve the animals alive.

obtained from anogenital distance and body weight with the simple linear model and the generalized linear model are: Age $=-5.50+0.37 D A G+0.01 P V$ with $R^{2}=$ 0.98 for males and $-7.42+2.13 D A G+4.8 .10^{-3} P V$ with $\mathrm{R}^{2}=0.96$ for females.

cuisse de l'aulacode (Thryonomys swinderianus, Temminck 1827), 2003, RASPA vol.1.

Edderai D, Ntsame M, Houben P, Gestion de la reproduction en aulacodiculture. Synthèse des outils et méthodes existants. INRA Prod. Anim., 14 (2), 2001, 97-103.

Farougou $\mathrm{S}$, Contribution à l'établissement des valeurs usuelles sériques chez l'aulacode mâle adulte (Thryonomys swinderianus, Temminck 1827), Thèse Med. Vet. Dakar, 1992, n²0-116p.

Heymans C, L'élevage de l'aulacode (Thryonomys swinderianus), Cahier conservation, $\mathrm{N}^{\circ} 31$, Rome, 1996, 98p.

Hounzangbe-adote MS, Bilombo AJ, Yewadan L, Hoste $\mathrm{H}$, et Moutairou $\mathrm{K}$, Evolution de la maturité sexuelle chez les aulacodes mâles en fonction de l'âge .Rev Med Vét, 2004, pp155

Jori $F$, Mensah GA, Adjanohoun E, Grasscutter farming: an example of rational utilization of wildlife. Biodiversity and Conservation 4, 1995, 257-265.

Le Louarn H, Détermination de l'âge par la pesée des cristallins chez quelques espèces de rongeurs, , Mammalia, 35(4), 1971, 636-643.

Marchandeau S, Guenezan M, Chantal J, Utilisation de la croissance pondérale pour la détermination de l'âge de jeunes lapins de garenne (Oryctolagus cuniculus) $=$ Weight increase as a criterion of age in young wild rabbits (Oryctolagus cuniculus). Gibier faunesauvage vol. 12 , no4, 1995, pp. 289-302. 
Martinet L, Détermination de l'âge chez le campagnol des champs (Microtus arvilis) par la pesée du cristallin, Mammalia, 30(30), 1966, 425-480.

Mensah GA, Ekué MRM, L'essentiel en aulacodiculture. RéRE/KIT/IUCN/C.B.D.D.République du Bénin/Royaume des Pays-Bas. ISBN: 99919-902-4-0, 2003, $160 \mathrm{p}$.

Mensah GA, Mensah ERCKD, Pomalègni SCB, Guide pratique de l'aulacodiculture, INRAB/PADFA/MAEP, Dépôt légal № 3551. du 06/11/2007, 4ème trimestre, 2007, Bibliothèque Nationale (BN) du Bénin, ISBN 1397899919-66-30-4, 2007, 127p.

Poulet A, Détermination de l'âge par la pesée du cristallin chez cinq espèces de rongeurs Muridés et Gerbillidés de l'ouest de l'Afrique, Mammalia, 44(3), 1980, 381-398.

Quéré JP, Vincent JP, Détermination de l'âge chez le mulot gris (Apodemus sylvaticus L.1798) par la pesée du cristallin, Mammalia t $53 \mathrm{n}^{\circ} 2$, 1989, 287-293.

Rosevear DR, The rodents of West Africa, Trustees of the British Museum (Natural History), 1969, London.

Sicard B, Kyelem M, Papillon Y, Diarra W, Keita M, Rongeurs nuisibles Soudano-Saheliens, Ed. Institut du Sahel, CTA-ORSTOM, 1995, 54p.

Yewadan TL, Schrage R, Abrégé d'élevage des aulacodes,

Rossdort, verlagsgesellsschaftmbH, GTZ, 1995, 103. 